\title{
The World-System of Giovanni Battista Riccioli and the Phases of Venus and Mercury
}

\author{
Flavia Marcacci \\ Faculty of Philosophy, Pontifical Lateran University, Vatican City \\ Email: flaviamarcacci@gmail.com
}

Received 16 April 2015; accepted 4 May 2015; published 7 May 2015

Copyright $\odot 2015$ by author and Scientific Research Publishing Inc. This work is licensed under the Creative Commons Attribution International License (CC BY). http://creativecommons.org/licenses/by/4.0/

\section{c) (i) Open Access}

\begin{abstract}
The Jesuit astronomer Giovanni Battista Riccioli (1598-1671) proposed an original astronomical system as an intermediate solution between the Copernican and the Ptolemaic systems. Many scholars describe his system as "geocentric", and so does Riccioli. He uses the Tychonic solution by adding a lot of differences, for instance, the order of the orbits and the movement of Jupiter and Mars. In his astronomical work, Riccioli is rigorous and serious and offers a great quantity of observational data. The analysis of these results is crucial to understand the evolution of the Copernican question during the first half of the XVII century. The article will look at some general lines of Riccioli's system, to understand how an astronomer of the XVII century really worked and to understand which problems the Copernican system could not resolve. Finally, I will try to consider some philosophical implications of this historical case.
\end{abstract}

\section{Keywords}

Giovanni Battista Riccioli, Phases of Venus, Phases of Mercury, Jesuit Science, Scientific Revolution

\section{Introduction}

Riccioli was an experienced and refined astronomer, who became a Jesuit when he was 16 . He taught theology and philosophy for several years in Parma and Bologna, while his interest in the new astronomical discoveries was growing. Therefore, he was very pleased when his superiors invited him to fully focus on astronomy. He was already nearly fifty but in a short time he could produce his major work, the Almagestum Novum (Riccioli, 1651). It was planned in three books, but only the first one was published in two volumes. Some years later, in 
1665, he published the Astronomia Reformata, that substituted in some measure the missing books (Riccioli, 1665). His works are considered the most important literary work of the Jesuits during the seventeenth century for their erudition, to the point that they are considered a summa of all astronomical production of that time.

Riccioli explored every important result of the contemporary astronomers and every meaningful idea of the ancient astronomers; at the same time, he produced experiments and geometrical demonstrations. In his Praefactio he expressed his desire to donate to his Order a biblioteca of every important recent astronomical topic: he knew his brothers did not have access to this type of literature.

The astronomy books by Giovanni Battista Riccioli (1598-1691) are ignored in T. Kuhn's The Copernican Revolution (Kuhn, 2002), and in the debate raised by his The Structure of the Scientific Revolutions (Kuhn, 2012), although they were universally used by XVII century astronomers. A few historians have begun to discuss them quite recently (e.g. Borgato, 2002; Graney, 2012), but they have focused on the epistemological implications of their research. In this paper, I introduce in a very general way the world-system of Riccioli and in a more particular manner his research about the phases of Venus. Then, I will try to delineate what the analysis of Riccioli's work should imply in our view of the birth of the modern science.

\section{Astronomical Problems in Riccioli's Astronomical Treatises}

In his astronomical treatises Riccioli studies the main problems of the astronomy of his age. For this reason, he dedicates fewer pages to the problem of the determination of the so-called trepidazione (displacement of the point of the equinox ${ }^{1}$ ) and the phenomenon of eclipses in comparison to the number of pages dedicated to the problems of the comparability between different astronomical systems and all the implicated problems. So Riccioli studies the motion of the primum mobilis (supposed separate to the sphere of the fixed stars ${ }^{2}$ ), of the Sun, of the Moon, of the Earth, of the five minor planets, he studies the eclipses, the sunspots and so on, always dealing with the geometrical and astrometrical questions in the vein of his contemporary astronomical praxis.

In the first half of the Seventeenth century, many astronomers are trying to compare the observational data to the different world-systems to understand which is the most exact and useful ${ }^{3}$. Riccioli does the same in the $\mathrm{Al}$ magestum Novum, including wide accounts on the history and theory of the different systems. Moreover, he compares the different geometrical and metrical results and he always rationally and impartially shows that errors and solutions are equally distributed among different systems. This verification seems to preclude a definite decision: for this reason he is proud to propose a solution of his own, based on his observational data ${ }^{4}$ or considerations, but he is also honest when he tries to give a halfway solution between his and others systems ${ }^{5}$.

Riccioli suggests a solution of his own for every kind of problem that emerges when a world-system is constructed. In Astronomia Reformata Riccioli describes his system (Prolegomena ad Astronomiam Reformatam, p. I-VIII): at the beginning he makes a summary of the scheme of the Exameron, then he speaks about the results of the other astronomers and reminds the experimental results about the fundamental astronomical phenomena; finally he proposes his system in a few words. This system is based on a lot of considerations and solutions that Riccioli elaborates to resolve the recurring problems of the astronomers.

Here is a brief list of the astronomical problems with a specific Ricciolian solution in the Almagestum Novum, solutions that are later elaborated in a coherent world-system ${ }^{6}$ (Table 1).

In a synthetic diagram, Riccioli offers this scheme of the word (Figure 1).

This scheme is indeed a compromise between the ancient Egyptian system and the Tychonic one (Figure 2

\footnotetext{
${ }^{1}$ See U. Baldini, Riccioli e Grimaldi, in Borgato, 2002: pp. 1-47, 12.

${ }^{2}$ See AN (Almagestum Novum) lib. IX, sectio II, cap. III, 254-262.

3“More exact and useful", not "real". The astronomers—not needly also "philosophers of nature"-are looking for a cosmic geometry and are not interested in the ontological problem of the reality behind the mathematical theory. About the problems of the comparison of the world-systems see F. Marcacci, From the sky to maps: observation and theory of the heavens between the 16th and the 18th century, in Magna longeque ad mirabilia. Astronomia e cosmologia nel fondo antico della Biblioteca Beato Pio IX, a cura di F. Marcacci, F. C. Panini e LateranUniversity Press, Modena—Città del Vaticano 2009, 24-52.

${ }^{4}$ Most of them were done with his assistant Francesco Maria Grimaldi (1618-1663). Cf. U. Baldini, Riccioli e Grimaldi, in Borgato, 2002: pp 1-47, especially the list of the observations and the experiments, quoted in Almagestum Novum and Astronomia reformata, with the relative dates in the apendix 1, 23-38.

${ }^{5}$ E.g. this is the case of the calculation of the longitude of Mars, Juppiter and Saturn (AN lib. VII, sectio II, cap. VII, 541-542.

${ }^{6}$ In this table I leave the specific problems of mensuration that Riccioli solved in an original way of him (e.g. the calculation of the distance Earth-Sun, the apparent diameters of the stars, the calculation of the terrestrial axis and so on) and I consider only general problems.
} 

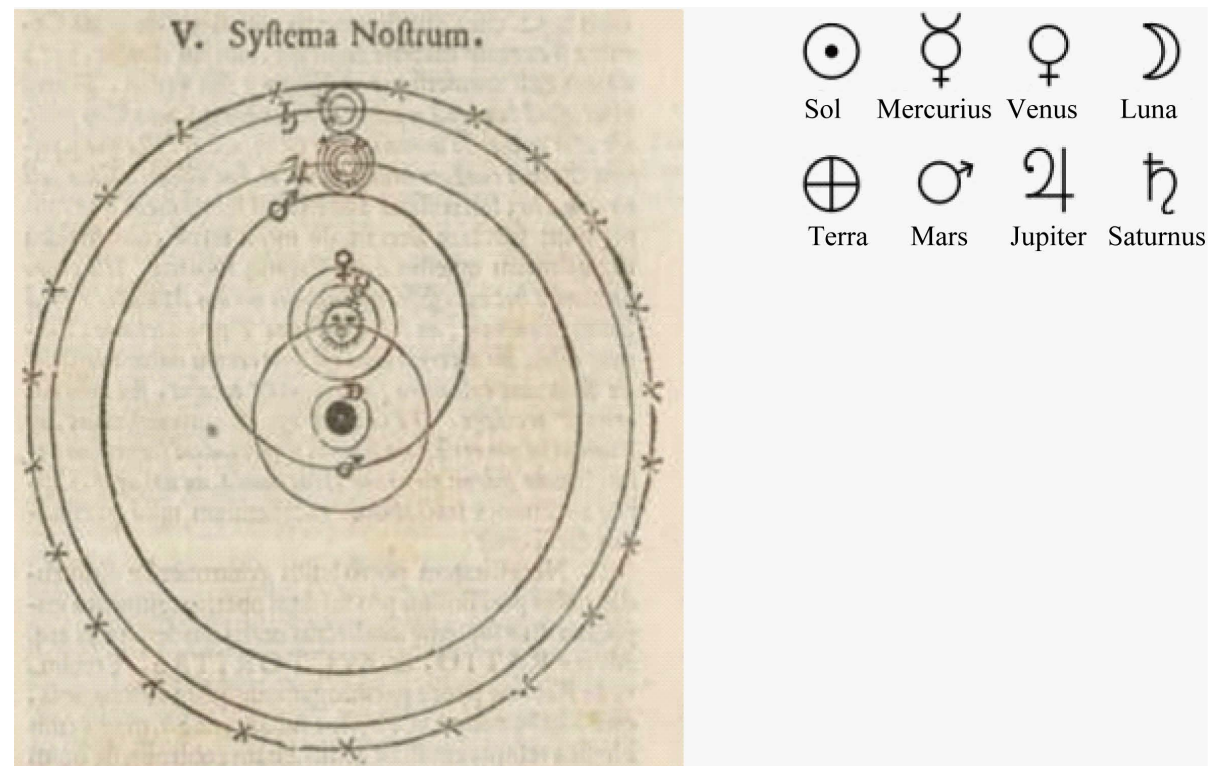

Figure 1. The world-system of Giovanni Battista Riccioli (AN 1. IX, s. III, c. IX, p. 288).

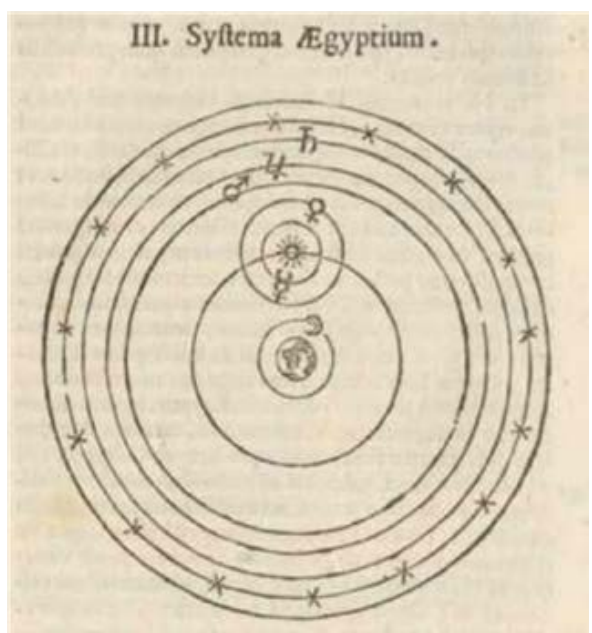

Figure 2. Ancient Egyptian world-system (AN l. IX, s. III, c. IV, p. 283).

and Figure 3), that Riccioli explains (together with the other world-systems ${ }^{7}$ ) before his system.

About the Egyptian scheme, Riccioli knows that it is basically an historical attempt on which he has not many details but only generic information by Vitruvius (80-15 b.C.), Martianus Capella (IV-V century), Ambrosius Theodosius Macrobius (fl. V cen.), the Venerable Bede (6732/3-735 a.C.) and more recently Andrea Argoli (1570-1657), "munitum demonstrationibus Geometricis, adiecta quantitate Eccentricitatum \& Epyciclorum" (AN lib. IX, sectio 3, cap. 4, p. 283). Riccioli considers the Egyptian scheme in order to complete his historical excursus but also for the importance of its conception. In effect in the Egyptian scheme the inferior planets Mercury and Venus revolve around the Sun, thus the Sun's orbit is the deferent for the two epicycles of Venus and

\footnotetext{
${ }^{7}$ In AN lib. III, cap. 6, 101-103 Riccioli explains the position of the Sun in the different world-systems (Pythagorean, Platonic, Egyptian, Copernican, Thyconian, Ricciolian). In AN lib. IX (De mundi systemate), s. III (De systemate mundi circa Terram immobilem) Riccioli explains also the Platonic system, the Ptolemaic system, and others. Particularly: c. II. IX Systema Antiquissimum \& Commune Pythagorae Ptolomei \& Plurimorum; c. III De Systemate Platonis, Platonicorum, Gebri, ac Theonis. Qua occasione disputatur de Cicerone Systemate; cap. IV De Systemate Aegyptiorum, seu Vitruuy, Martiani Capellae, Macroby, Bedae, \& Argoli; cap. V De Systemate Eudoxi, Calippi \& Aristotelis; cap. VI De Systemate Auerrois, Alpetragy, Delphini, \& Io. Bapt. Amici; cap. VIII De Systemate Io. Bapt. Turriani \& Hieronymi Fracastorij; cap. IX Et Systemate, Tychonis, Longomontani, Blancani \& multorum Tychonis sectatorum; cap. IX De Systemate Nostro.
} 
Table 1. Astronomical problems in the Almagestum Novum.

\begin{tabular}{|c|c|}
\hline Argumentum & Locum (liber, section, caput; page) \\
\hline \multicolumn{2}{|l|}{ More table copy ${ }^{\mathrm{a}}$} \\
\hline Systema nostrum & $\begin{array}{l}\text { l. III, c. VI; p. } 103 \\
\text { l. IX, s. III, c. IX; p. 288-289 }\end{array}$ \\
\hline Superior planets & l. VII, s. II, c. VI; p. 535-541 \\
\hline Planets' equation of motion & l. VII, s. II, c. XII; p. 555-561 \\
\hline Inferior planets & $\begin{array}{l}\text { l. VII, s. III; p. 561-567, 583-587, 593-595; } \\
\text { l. VII, s. IV, c. VII; p. 630-631 }\end{array}$ \\
\hline Size of the Earth & l. II, c. VII; p. 62-63 \\
\hline Position of the Earth in the world-system & $\begin{array}{l}\text { l. II, c. II; p. } 49 \\
\text { l. IX, s. III, c. II-VIII; p. 276-288 }\end{array}$ \\
\hline Four motions of the Earth & l. III, c. III; p. 51-52 \\
\hline $\begin{array}{l}\text { Method to calculate the eccentricty and } \\
\text { the apogee of the Sun's orbit }\end{array}$ & l. III, c. XXIV; p. 153 \\
\hline Parallaxis of the Sun & l. III, c. VIII; p. 113 \\
\hline Middle motion of the Sun & l. III, c. XVII; p. 140 \\
\hline Precession of the equinoxes & l. III, c. XXVIII; p. 167 \\
\hline $\begin{array}{l}\text { Distinction between the First Moble and } \\
\text { the sphere of the Fix stars }\end{array}$ & l. IX, s. II, c. 3; p. 254 \\
\hline Selenography & l. IV, c. VII, p. 203-205 \\
\hline Theory of the Moon & l. IV, c. XII; p. 218 \\
\hline Planetary Spiral orbits & $\begin{array}{l}\text { l. VII, c. VI; p. 535-541 } \\
\text { l. VII, c. VII; p. 541-542 }\end{array}$ \\
\hline
\end{tabular}

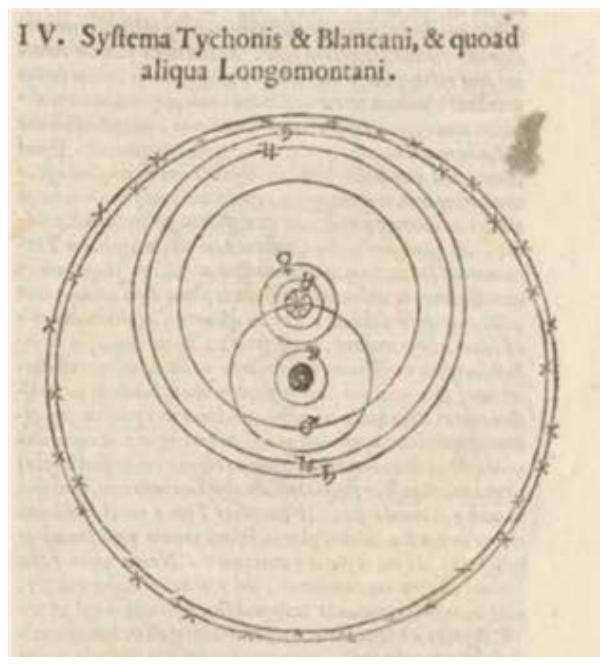

Figure 3. Tycho's (and others') world-system (AN l. IX, s. III, c. VIII, p. 287).

Mercury; the other planets revolve around the Earth. On the other hand the Tychonic scheme is associated with other astronomers such as the Aristotelian Jesuit Blancanus-Giuseppe Biancani (1566-1624), the student of Tycho Brahe Longomontanus - Christian Serensen Longomontano (1562-1647) and other multorum Tychonissectarum (p. 287) such as Giovanni Antonio Magini (1555-1617) and Christoph Scheiner (1573-1650).

Actually, Riccioli claims that a semi-Ptolemaic system and a semi-Tychonic system are better than the others, 
although the eccentricities of the orbits have to be measured ${ }^{8}$. But after a while he states that the Egyptian system is preferable regarding the planets'order ${ }^{9}$. Thus he opts for a totally different solution about the number of the skies. His system - writes Riccioli-has an unmovable Earth in the center of the world; next to it there is the orbit of the Moon and above it the orbit of the Sun, with a revolving Mercury and after Venus that revolves around Mercury; sometimes they are above and sometimes below the Sun. Thus Mars encircles Venus ${ }^{10}$. Above Mars there is Jupiter, which passes around four satellites, that trace their epicycles around it. Above Jupiter there is Saturn, with two bodies at its sides ${ }^{11}$. All these go freely around in a unique fluid sky by spirals ${ }^{12}$ with a unique oblique motion by the Intellects ${ }^{13}$ toward the West. Above Saturn there is the solid sphere of the Fixed-stars that has a unique motion similar to a spiral and that exhibits a triplex motion, exactly in longitude toward the West, in longitude toward the East and in latitude by difference of the declination: the result is a motion toward the West ${ }^{14}$. Above the sphere of the fix stars there is the crystalline sky (Riccioli doesn't make conjectures about its use) and farther above the habitaculum Beatorum ${ }^{15}$.

\section{New Evidences for the New Science}

The satellites of Jupiter, the phases of Venus and Mercury, the rings of Saturn, the elliptical orbits and the motion of the Earth are the new questions that needed an explanation. We neglect now the motion of the Earth, a question that involved Riccioli (Riccioli, 1668, 1669; Degli Angeli, 1667, 1668a, 1668b, 1669; Borelli, 1667, 1668) and about that there is a sufficient literature (Borgato, Riccioli e la cadutadeigravi in Borgato, 2002: pp. 79-118; Galluzzi, 1977; Di Teodoro, Bedogni, \& Bònoli, 2010): the motion of the Earth was completely understood and demonstrated only long after.

About the other quoted questions, we should pay more attention: on one hand the satellites of Jupiter, the

\footnotetext{
8“Post varia priscorum ac recentiorum systemata, Terrae immobilitate innixa, duo tandem mihi post Tychonicum, probabiliora videtur: unum semiPtolemaicum, alterum semiTychonicum, quod centrum, a quo Eccentricitates orbium mensurandae sunt” (AN lib. IX, sectio 3, cap. 9, 288-289).

${ }^{9}$ See also AN lib. VII, sectio 1, cap. 4, 493-495.

${ }^{10}$ Riccioli writes after: "Martem autem esse maximum satellitem Solis" (ivi, 289).

${ }^{11}$ Riccioli writes "lateronibus stipatus" Certainly Riccioli understands the two figures at the sides of Saturn, that he observes when he tries to verify the Galileo's discover with the telescope (and who described the ring as having "ears" or "tricorporeo", "tripled-bodied". See Lettera di Galileo a Giuliano de' Medici in Praga del 10 dicembre 1610, in A.Favaro (ed.), Opere di Galileo, vol. X, G. Barbera, Firenze 1934, 483). In AN lib. VII, sectio 1, cap. 5, 487-488 (see the figure below) he represents the rings of Saturn with the image I (observation of Bologna in same days in October 1643 after the opposition with the Sun), the image II (on May 23, 1643), the images III and IV (during the period 1633 and 1646). Riccioli seems to think to Saturn with two "comitibus" that sometimes are "semilatentibus" (ivi, 488), so he can write "Saturnum...et Iovem...suos circa se Planetas habere” (ivi, 289).
}

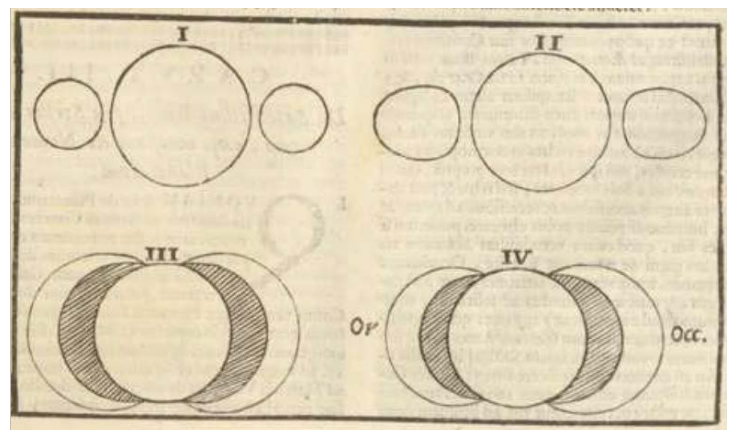

\footnotetext{
${ }^{12}$ Riccioli considers the motion of the planets as spirals, see Casanovas, L'astronomiadopo Keplero, in Borgato 2002: pp. 119-131.

${ }^{13}$ As Casanovas observes, in this kind of argument we have to intend "Intellect" as anima or as our "force" (Casanovas, L'astronomiadopo Keplero, in Borgato, 2002: 119-131, 124).

14،... triplicem motum apparenter exhibens, nempe in longitudinem ob declinationis variationem, qui tamen reuerà unicus est in Occidentem (289).

${ }^{15}$ “In eo enim Terram in mundi centro ab omni motu immunem collocamus, \& circa ipsam Lunae orbem , supra quem ita Solis circulario versatur, ut tamen circam Solem Mercurius, \& circa Mercurium Venus circumagatur, \& aliquando supra Solem, \& aliquando infra reperiantur: deinde ita Mars Venere ambit, ut in oppositione cum Sole propius ad Terram quàm Sol accedat. Supra Martem eminet Iupiter, quatuor satellites circumferens, qui circa ipsum suos epyciclos describunt; \& supra Iovem Saturnus, duobus \& ipse comitibus, seu lateronibus stipatus: qui omnes in unico reipsà coelo fluido liberè per spiras helicoides, seu cochleatim ad Intelligētijs unico moto versùs Occidentem obliquè circumducuntur. Supra Saturnum est solida fixarum sphaera per unicum spiralem item motuum apparenter exhibens, nempe in longitudinem od declinationis variationem, qui tamen reuerà unicus est in Occidentem. Supra Fixarum spheram est caelum aqueum, seu crystallinum, ad eum usum, qui Deo notus est, \& supra hoc Empyreum immobile, admirabili splendora coruscans, \& felicissimum ac sempiternum habitaculum Beatorum” (AN lib. IX, sectio 3, cap. 9, 289).
} 
phases of Venus and Mercury and the rings of Saturn were really discovered and observed, and forced the astronomers to create an explanation; on the other hand, many astronomers, such as Galileo, did not like the elliptical orbits of Kepler, that seemed an artful reworking of the Ptolemaic punti aequantes ${ }^{16}$.

All these problems have to be inserted in an astronomical context where the alternative was not strictly between the Ptolemaic and the Copernican systems. The alternative was between the Copernican solution and the Tychonic one, and we would make a mistake if we forget this. Therefore, their first attempts were to try to explain these questions in the context of the astrometrical techniques: Riccioli's solution is one of these and he succeeds in embedding these items in his system. Here I analyze only the question of the phases of Mercury and Venus in Riccioli's system with more details.

\subsection{The Phases of the Inferior Planets}

Riccioli recalls that thanks to the invention of the telescope the astronomers have been able to look at many celestial objects and particularly to observe more clearly the phases of the inferior planets. Riccioli studies this phenomenon in AN lib. VII, sectio I, cap. II, p. 483-484. The Latin names used in XVII century for the phases of planets were:

rotunda (as in position $\mathrm{C}$ )

gibba (as in position E, D)

bisecta (as in position F, G)

falcate (as in position $\mathrm{H}, \mathrm{I}$ ).

In reference to the Figure 4, Mercury and Venus seem to be falcate (provided with a sickle) when they are observed after the sunrise (position I). When the distance from the Sun is the greatest they are bifidi (divided in two parts, as the Moon "ac Lunaedichotomaespeciem imitates"-position G). Afterward they seem to be gibbi (position E) and slowly lead up to the rounded shape (position C, Apogeaconniunctione). The planets continue their path at the same way, until the perigee in coniunctione cum Sole (position K): here, when they are near the Sun and below its brightness, they are visible very infrequently or, because of the small latitude, they hide a little part of the Sun as a dark $\operatorname{spot}^{17}$.

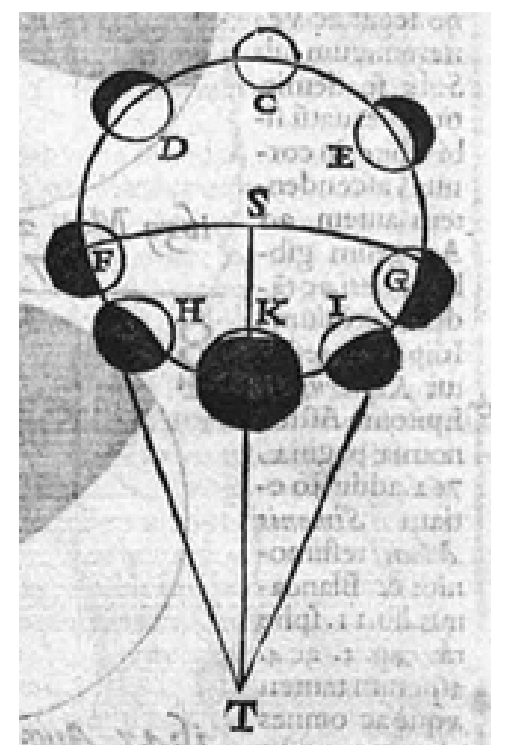

Figure 4. Phases of the inferior planets (AN l. VII, s. I, c. II, p. 483-483).

\footnotetext{
${ }^{16}$ See Casanovas, L'astronomia dopo Keplero, in Borgato, 2002: 119-131, 123. Kepler, in his long itinerary to determine the form of Mars' orbit, obviously considered models with the punctum aequans. In a first phase, he thought of a position of the punctum aequans different from Ptolemy's, after that he adopted the bisection of eccentricity as Ptolemy (a quite long series of considerations justifies his choice). Furthermore, in the Keplerian ellipses, it is possible to say that the focus in which there is not the sun, can be seen as a punctum aequans.

${ }^{17}$ “'In coniunctione autem cum Sole facta in Perigeo K, diebusq. utrimq. Proximis latent sub splendoribus Solis, necvidentur, nisi rarissimè, aut propter exiguam latitudinem occultantes particulam Solis nigerrimae instar maculae”. The reference is obviously to a transit of Mercury and Venus.
} 
Riccioli reveals that the small latitude and the short distance from the Sun are the fundamental problems for looking at these two planets. He refers to Tycho's observations of Venus near the conjunction at the perigee, under a latitude of 9 degrees.

So Riccioli introduces the most powerful argument to establish if Mercury and Venus go around the Sun ${ }^{18}$ : because the distance between these planets and the Sun would never be superior than 29/30 degrees for Mercury and 50 degrees for Venus ${ }^{19}$, if Mercury and Venus went round the Earth then they could be observed often sickle-shaped (falcati) or halved (dichotomi) with the telescope. On the contrary, if they always went above the Sun, then they could always be observed rounded or quasi-rounded with a complete cycle of phases ${ }^{20}$.

\subsection{The Phases of Mercury}

This argument is known to astronomers, and Riccioli is conscious. He declares also the difficulty to observe Mercury because the atmosphere rarely gives the opportunity to observe the falcatum Mercury ("à Sole vaporesq. horizontis, rarò dato opportunitas eum falcarum videndi”, AN lib. VII, sectio I, cap. II, p. 484). Despite of this, a lot of his colleagues theorized or observed the phases (see Figure 5): he quoted Scheiner, who understood that the geometry of the motion of Mercury could cause the phases; and he quotes Galileo, Martin van den Hove (Hortensius, 1605-1639), Kepler, Francesco Fontana (1585?-1656) and Battista Zupi (1590-1650). About the last one, he seems to have been the first astronomer who succeeded in observing the phases of Mercury in the 23th May 1639 in Naples. Fontana observed the same phases during the days 26th January 1646 (around 22 degrees). Riccioli observes an analogous phase during the sunset in 30th April 1647 (degrees 20.5), and another phases during the sunshine in 25 August 1643 (19 degrees), in 6th August 1644 (20 degrees), during the sunset

AN lib.VII, sectio I, cap. II, p.484

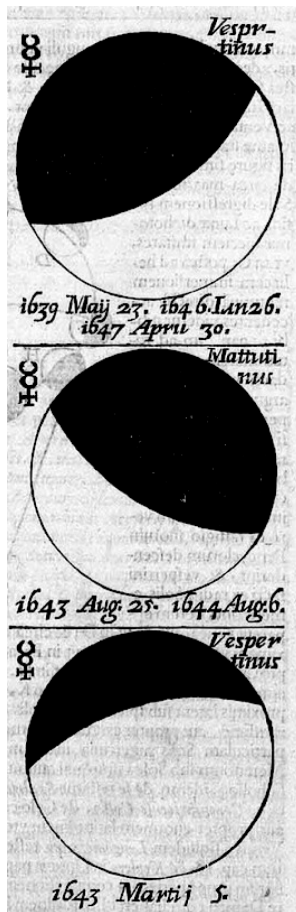

Zupi, 23th May 1639

Fontana, 26th January 1646 (ca. $22^{\circ}$ )

Riccioli, 30th April 1647 (20,5 $)$

Riccioli,25th August $1643\left(19^{\circ}\right)$

Riccioli,6th August $1644\left(20^{\circ}\right)$

Riccioli,5thMarch1643(15)

Figure 5. Phases of mercury (AN l. VII, s. I, c. II, p. 483-483).

\footnotetext{
${ }^{18}$ This was effectively the big intuition of Copernic: he thought that, if the inferior planet never distance from the Sun further that a small quantity, then they have to round the Sun and the Earth round the Sun more externally than them. See Small, 1804.

${ }^{19}$ Mercury's elongation is between $18^{\circ}$ and $28^{\circ}$, while Venus's elongation reaches a maximum of $47.8^{\circ}$.

20، Tycho Venerem prope perigeam coniunctionem vidit in Horizonte Danico, cùm haberet Latitudinem Borealem Grad.penè 9. His ita se habentibus, argumentum consicitur validissimum, Planetas hosce ambire Solem S; \& ab eo illustrari: Nam si semper infra ipsum sequerentur, nūquam digredientes ab eo Merc. ultra 29. aut 30. Ven. ultra 50. Gradus, semper falcati aut dichotomi ad summùm Telescopio apparerent; si autem semper supra Solem versarentur, semper rotundi: aut quasi rotundi, ut inspectione ipsa schematis, \& ductis lineis illuminationis reflexionisq. inde ad oculos nostros iuxta regulas Opticas, patebit; si verò à seipsis circumquaq. Lucerent, semper rotundi viderentur. Sed iam de ipsis singillatim agendum est”, AN lib. VII, sectio I, cap. II, 483-484.
} 
in 5th March 1643 (15 degrees). Let's look at Figure 5.

Riccioli concludes: "Neque opus est alias observationes addere: Iamenim extra controversiam est apud recentiores Telescopij observandiq. peritos; Mercurium eodem modo à Sole illuminari ac Lunam, si Luna Solem potiùs quàm Terram circuitu suo ambitet”. Thus, the observational data are clear: in the correct world-model Mercury has to rotate around the Sun.

\subsection{The Phases of Venus}

For the phases of Venus Riccioli says Venus appears rotunda, gibba, bisecta and falcata often and clearly. He debates always in the same way: first of all he recalls the astronomers who said to have observed the phases of Venus (Galileo, Biancani, Scheiner), after he adds that Venus generally appears rounded and little ad coniunctionem matutinam cum Sole, while it appears rounded and forty times largest when it is retrograda ...ad coniunctionem vespertinam (AN, p. 484). After the second quadrature with the Sun at $90^{\circ}$ (quando bisecta apparet, see the Figure 6), Venus appears horned and for this reason its shine is weak. Riccioli says to have observed Venus frequently silck-shaped (saepissime falcatam) and always flamboyant (flammiuomam), sed never halved (bifidam) or hunchbacked (gibbam). With the Fontana's telescope Riccioli observes Venus in this shape, in 9th January 1643 (see Table 2).

Riccioli writes Venus seems to be blond in its center and cerulean blue in the part opposite to the Sun: he presumes these effects are caused by the telescope (as a phenomenon of refraction). There was a shiny half-ring, which crowed Venus backward, and perhaps caused by eastern Saturn and Jupiter.

Venus has been observed many times in 1644, when Venus arrives to the apogee of its epicycle during its setting, particularly after heliacal evening risings ${ }^{21}$ :

After his observations, Riccioli recalls shortly the observations by Francesco Fontana (1646, tractatus 5, caput 2, see Figure 7):

(1) in the date $22^{\text {th }}$ January 1643 (in Fontana, 1646: curniculata...quasi bislonga, p. 92);

(2) in the date $11^{\text {st }}$ November 1645 Venus appears with a little ball in the center, purple and with shadows (in Fontana, 1646: in medio corpore...pilula quaedam punicejadumbratis coloris, p. 94);

(3) $15^{\text {th }}$ November 1645 Venus seems sickle-shaped and with fibers around the vague edges (in Fontana, 1646: cum ante Veneris cornua collocant... radiorum multitudinem impedire perfectam cornuum terminationem conspici posse, p. 96);

(4) $25^{\text {th }}$ December 1645, Venus appears with two little globes (in Fontana, 1646: globulis, p. 98);

(5) $22^{\text {nd }}$ January 1646, Venus seams with horns and with a little globe or pill (in Fontana, 1646: globulus vel pilula, p. 100);

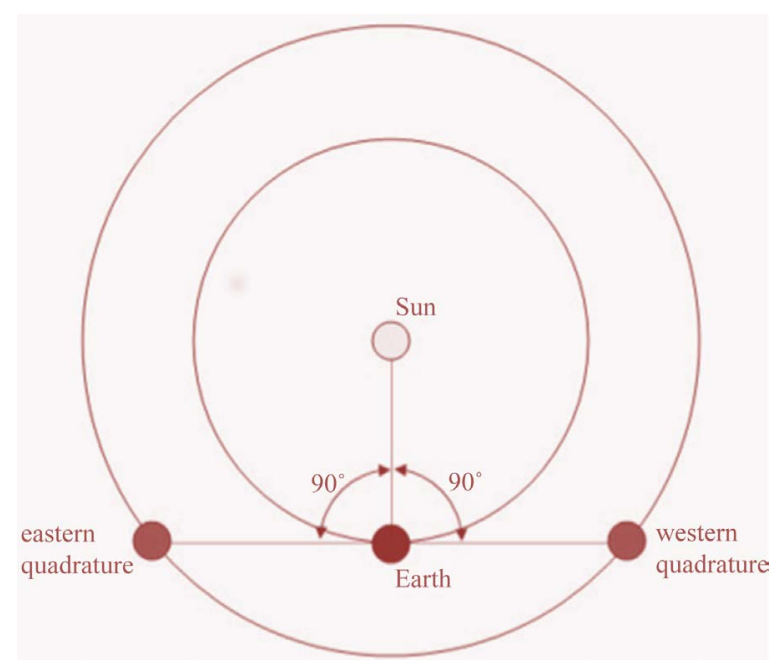

Figure 6. Quadrature.

\footnotetext{
${ }^{21}$ For the stars, the planets, the constellation and the moon generally we can distinguish: the Heliacal rising (ortus heliacus) when the celestial body (after a period when it was invisible) rises in the morning before the sunrise (or in the evening before the sunset) and it first becomes visible in the twilight because the Sun is still far enough below the eastern horizon; the heliacal setting of the planet is the last time the planet can be observed and after this moment it has occulted by the Sunlight at the morning or at the evening (occasus heliacus).
} 
Table 2. Observations of Venus.

\begin{tabular}{|c|c|c|}
\hline 1644 & 7th May-20th June & 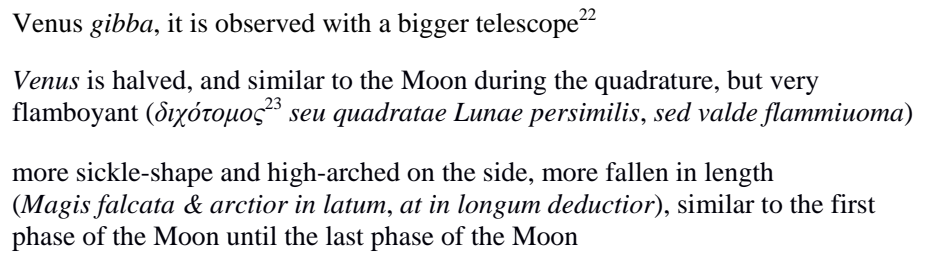 \\
\hline \multirow{5}{*}{1649} & $\begin{array}{l}\text { 29th June } 1649 \\
\text { (near to the apogee of the Eccentric) }\end{array}$ & $\begin{array}{l}\text { Venus is observed for the last time very shine and similar to the last } \\
\text { phase of the Moon }\left(\text { Hoc modo... }^{24}\right. \\
\text { Luculentissime Vesperugo }{ }^{24} \text { ultimò visa est per tubum occasu heliaco } \\
\text { vespertino) }\end{array}$ \\
\hline & after & $\begin{array}{l}\text { Venus has very high pitched horns and very tidy edges, and it seems to have a } \\
\text { bright fibers and hair }\end{array}$ \\
\hline & $\begin{array}{l}\text { 7th July (near to the apogee of the } \\
\text { eccentric, and in motion in the } \\
\text { direction of the perigee of the Epicycle) }\end{array}$ & Venus is joined to the Sun \\
\hline & (invisible for the clouds during a few days) & \\
\hline & 18th July & $\begin{array}{l}\text { Venus appears as a sickle with the acute tips and a weak light while it } \\
\text { goes toward the West Matutinam in Oriente apparebat, cornibus nitidissimè } \\
\text { acutis ad Occidentem conuertis, falcata, debili ac diminuto lumine, quamuis } \\
\text { Lucifer seu Phosphoros }\end{array}$ \\
\hline
\end{tabular}

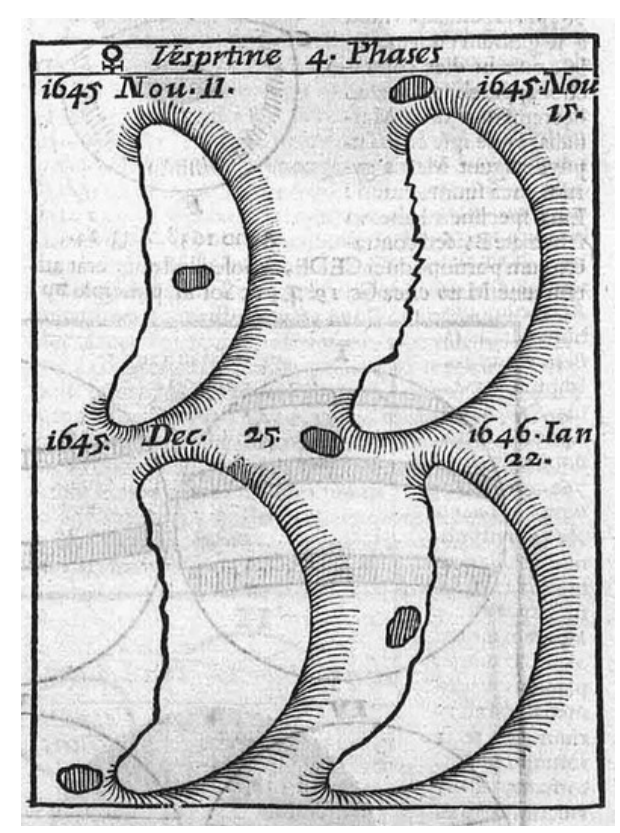

Figure 7. Fontana's phases of Venus in Riccioli (AN lib. VII, sect. I, cap. II, p. 485).

(6) $14^{\text {th }}$ March 1646, Venus has the little horns and is circled with rays (in Fontana, 1646: curniculata, \& paucioribus, ac praecedens, circundata radijs, p. 102).

Riccioli reproduces the same Figure 7, but he expresses his doubts because neither Fontana has clarified the nature of these little globes or pills, nor above all have ever other astronomers (as Grimaldi, Gassendi and Ricci-

\footnotetext{
${ }^{22}$ Riccioli does not tell us how big.

${ }^{23}$ Maybe Riccioli makes a mistake: the world would be $\delta$ íóto $\mu \alpha \varsigma$.

${ }^{24}$ Latin name to indicate Venus when appears as the "last star" of the evening.
} 
oli himself) observed such globes or pills.

Finally Riccioli reproduces a text by De Civitate Dei 8.2 where S. Augustine recalls Marcus Terentius Varro who describes Venus (116-27 b.C.) as the star that changed color, size, shape and course: the extraordinary appearance of Venus has known since immemorial time.

\subsection{Conclusive Remarks about the Phases of the Inferior Planets}

Riccioli opts for a geocentric system because this kind of solution does not contrast with the observational data. The phases of Venus and Mercury are also allowed in this kind of system. He has to exclude the Ptolemaic geocentricism strictu sensu. For this reason I think that when he calls himself "Ptolemaic" (as we said at the beginning of this abstract) he is thinking about the quality of a geocentric world-system to be "with the Earth in the center". Nothing else. Notwithstanding he might want to justify his position before the Inquisition Tribunal for evading the charge to support the heliocentrism.

But about the problem of the phases of Venus and Mercury, from an astronomical point of view, Riccioli has no reasons to prefer the Copernican solution. On the score of the verification of the phases of the inferior planets, Riccioli is sure that the inferior revolves around the Sun, but independently from the movement of the Earth.

\section{General Conclusion}

Definitive astronomical proofs of the rotational and revolutionary motion of Earth were given only by Guglielmini (1789, experiments at the Torre degli Asinelli in Bologna), recovered by Tadini (Giannini, 2012), Bradley (stellar aberration, 1728), Calandrelli (1806, stellar parallaxes of Vega) ${ }^{25}$ and Foucalt (1851, the experiment of the pendolum): the astronomy started the so-called "Scientific Revolution", but it could not bring it to a conclusion by the end of XVII century. The "new science" won slowly thanks to other sectors of sciences, as mechanics. The Copernican theory is not definitively accepted completely due to the new discoveries, but because of a deeper knowledge of the reality for a long time: the astronomical revolution is not a chronologically short event.

From an epistemological point of view, the comparison between the different systems of world seems to fall down the principle that a theory wins for his major connection with the empiric data. It seems we cannot choose among alternative theories just by comparing them with a series of data, but we always rely heavily on background assumptions and available (theoretical and practical) instruments.

More strongly, it seems that erroneous theories could be implied by data unexpectedly and coherently: in the Riccioli's case we can certify the consideration of the observational data and the continuity between the observations and theoretical claims. After the examination of alternative theories and of the experimental and observational results Riccioli declares his preference for a (semi)geocentric system as the best solution. By using the instruments of astronomy of his time, he did the best ever. Thus, it would be a mistake to evaluate the XVII century epistemic situation in hindsight, as if today's instruments and knowledge were available at that time. Actually the instruments and the data to decide for the heliocentrism in the Keplerian version will arrive only some decades after the death of Riccioli, when the Newtonian synthesis will be ready and the new discovers will be done.

The presence of intermediate theories such as Riccioli's planetary theory, attests how moving from one paradigm to another, to quote Kuhn, is difficult. Moreover, it demonstrates the strange case that, in the words of Laudan (Laudan, 1981), a false theory, that already has long resisted, may continue to resist, even after the formulation of a viable alternative theory. In short words, the same data for different theories refer to the same single reality. Does science produce ultimately only weak outcomes of human knowledge? If this is so, then a scientific theory is never an explanation, rather "It is a system of mathematical propositions, deduced from a limited number of principles whose aim is to represent in the simplest, most complete and exact way a set of experimental laws" (Duhem, 1978: p. 24). As a result, the history of science becomes an activity that is dedicated to the story of the subsequent descriptions of the world. It is unknown why these explanations can talk about reality.

\footnotetext{
${ }^{25}$ The discovery by James Bradley in 1728 of the aberration of the stellar light needed a theory of light to be completely accepted. The aberration, in fact, depends on the motion of the observer and on the finite velocity of the light; particularly it depends on the velocity of the Earth that revolves around the Sun. Bradley himself formulated any hypotheses about the cause of the phenomenon (e.g. the terrestrial nutation), not concluding that it is strictly connected with the terrestrial revolution. The stellar parallaxis is caused by a change in the position of the observer on the Earth looking at the stars or other object: Calandrelli in 1806 measured the parallaxis of the star Vega, but the measurement was not correct and underestimated. However, it was the first physical measurement of the terrestrial revolution. In force of this result, Giuseppe Settele, professor at the University La Sapienza in Roma, obtained the Imprimatur of his manual of Copernican astronomy by the Holy Office.
} 
If one does not accept this position, one must first use jointly historical and epistemological analysis, to understand how and about what one constructs the history of science. One gets respectively a historical history of science and epistemological history of science. The historical history of science would principally be written using the standard methods of historical research (such as textual and contextual analysis, the appeal to philology, and so on); in the epistemological history of science what matters the most are the theoretical perspective useful to produce the historical reconstruction. The two views have to, however, interact, otherwise the history of science oscillates between two opposite poles: absolutizing history and relativizing knowledge (historicism) or relativizing history and submitting it to knowledge (idealism). How to respect the historical data without producing a skeptical historicism and at the same time how making an historical work that shows the advancement of knowledge? At least, the epistemological and historical history of science has to interact continuously: in this way neither historicism nor idealism is the unique perspective on the method of the history of science.

A question remains: does the history of science obtain the explanation of reality or the reality's representations in sequence? If our philosophical perspective embraces some form of scientific realism, then the answer must be that the history of science talks about the explanations of reality. If the history of science is referred to a phenomenalist representations of reality, then the science is convention. An inquiry aimed at understanding "what are the objects of the history of science" is necessary. A scientific object, such as the planetary orbits, is the sum of observational data and concept useful to organize it. Both data and their conceptualization have a historical evolution. Thus, a "historical ontology of science" may reflect on the historical constitution of objects of science (Marcacci, 2015). Then one might understand why a theory after the other describes parts of the true reality. The history of science is not the succession of representations of reality but a discipline where parts of reality are combined in historically ways.

\section{References}

Borelli, G. A. (1667). De vi percussionisliber. Bologna: Typographia I. Monti

Borelli, G. A. (1668). Risposta di Gio. Alfonso Borelli ... alle considerazioni fatte sopra alcuni luoghi del suo Libro della forza della percossa del r.p.f. Stefano de gl'Angeli. Messina.

Borgato, M. T. (2002). Giambattista Riccioli e il merito scientifico dei Gesuiti nell'età barocca. Firenze: Leo S. Olschki.

Degli Angeli, S. (1667). Considerationi sopra la forza di alcune ragioni fisicomattematiche, addotte dal m.r.p. Gio. Battista Riccioli ... nel suo Almagesto nuouo\& Astronomia riformata contro il sistema copernicano, espresse in due dialoghi da $f$. Stefano de gli Angeli veneziano, Mattematico nello Studio di Padova. Venetia: Appresso Bortolo Bruni

Degli Angeli, S. (1668a). Seconde considerationi sopra la forza dell'argomento fisicomattematico del m. reu. p. Gio. Battista Riccioli...contro il moto diurno della terra, spiegato dal sig. Michiel Manfredi nelle sue Risposte e riflessioni sopra le prime Considerationi di f. Stefano de gl'Angeli...espresse da questi in due altri dialogi III e IV, Padoua: Per Mattio Bolzetta de Cadorini.

Degli Angeli, S. (1668b). Terze considerazioni sopra vna Lettera del ... signor Gio. Alfonso Borelli ... scritta da questi in replica di alcune dottrine incidentemente tocche da fra Stefano degl'Angeli ... nelle sue prime Considerationi sopra la forza di certo argomento contro il moto diurno della Terra espresse da questo in vn dialogo quinto in ordine. Venetia: appresso li heredi Leni.

Degli Angeli, S. (1669). Quarte considerationi sopra la confermatione d'una sentenza del sig. Gio. Alfonso Borelli ... prodotta da Diego Zerilli contro la Terze considerationi di Stefano degli Angeli \&c e sopra l’Apologia del m.r.p. Gio. Battista Riccioli ... a fauore d'un suo argomento detto fisico-matematico contro il sistema copernicano/espresse dal medesimo Stefano de gl’Angeli ... in due dialogi VI. e VII. Padoua: Per Mattio Cadorin detto Bolzetta.

Di Teodoro, E. M., Bedogni, R., \& Bònoli, F. (2010). I primi esperimenti sulla caduta dei gravi: Galileo e Riccioli. Giornale di Astronomia, 36, 32-40.

Duhem, P. (1978). La teoria fisica. Bologna: Il Mulino.

Fontana, F. (1646). Novae coelestium terrestriumq[ue] rerum observationes et fortasse hactenus non vulgatae a Francisco Fontana specillis a se inventis et ad summam perfectionem per ducti seditae. Neapoli: apudGaffarum. http://www.e-rara.ch/

Galluzzi, P. (1977). Galileo contro Copernico. Il dibattito sulla prova "galileiana” di G. B. Riccioli contro il moto della Terra. Annali dell'Istituto e Museo di storia della scienza di Firenze, 2, 87-148. http://dx.doi.org/10.1163/221058777X01352

Giannini, G. (2012). Verso Oriente. Gianantonio Tadini e la prima prova fisica della rotazione terrestre. Florence: Leo S. Olschki.

Graney, C. (2012). 126 Arguments Concerning the Motion of the Earth as Presented by Giovanni Battista Riccioli in His 
1651 Almagestum Novum. Journal for the History of Astronomy, 43, 215-226.

Kuhn, T. S. (2002/1957). The Copernican Revolution: Planetary Astronomy in the Development of Western Thought. Cambridge: Harvard University Press.

Kuhn, T. S. (2012/1962). The Structure of the Scientific Revolutions. Chicago, IL: The University of Chicago Press.

Laudan, L. (1981). A Confutation of Convergent Realism. Philosophy of Science, 48, 19-49.

Marcacci, F. (2015). History of Science, Epistemology, Ontology. In G. Tarozzi, \& M. Alai (Eds.), Evandro Agazzi in the Contemporary Scientific and Philosophical Debate. Berlin: Springer, Forthcoming.

Riccioli, G. B. (1651). Almagestum novum astronomiam veterem novamque complectens [Microform]: Observationibus aliorum, et propriis novisque theorematibus, problematibus, ac tabulis promotam: In tres tomos distributam quorum argumentum sequens pagina explicabit. Bononiae: Ex Typographia Haeredis Victorij Benatij.

Riccioli, G. B. (1665). Astronomiae reformatae tomi duo, quorum prior observationes, hypotheses et fundamenta tabularum, posterior praecepta pro usu Tabularum Astronomicarum, et ipsas tabulas astronomicas 102 continet. Prioris tomi in decem libros divisi, argumenta pagina sequenti exponitur. Auctore P. Ioanne Baptista Ricciolo. Bononiae: Ex typographia haeredis Victorij Benatij.

Riccioli, G. B. (1668). Argomento fisicomattematico del Gio. Battista Riccioli... contro il moto diurno della Terra confermato di nuovo con l'occasione della Risposta alle considerazioni sopra la forza del detto argomento etc. fatte dal M. R. Fr. Stefano de gli Angeli... Bologna: Per Emilio Maria, e fratelli de’Manolessi.

Riccioli, G. B. (1669). Apologia r.p. Io. Bapt. Ricciolii... pro argumento physicomathematico contra systema Copernicanum adiecto contra illud novo argumento ex reflexo motu gravium decidentium. Venetiis: Apud Franciscum Salerni \& Ioannem Cagnolini.

Small, R. (1804). An Account of the Astronomical Discoveries of Kepler. Madison, WI: The University of Wisconsin Press. 